\title{
Does plasmin have anticoagulant activity?
}

This article was published in the following Dove Press journal:

Vascular Health and Risk Management

30 March 2010

Number of times this article has been viewed

\author{
Jane Hoover-Plow \\ Joseph J Jacobs Center for \\ Thrombosis and Vascular Biology, \\ Departments of Cardiovascular \\ Medicine and Molecular Cardiology, \\ Lerner Research Institute Cleveland \\ Clinic, Ohio, USA
}

Correspondence: Jane Hoover-Plow Department of Molecular Cardiology, NB50, Cleveland Clinic Lerner Research Institute, 9500 Euclid Avenue, Cleveland, $\mathrm{OH} 44195$, USA

Tel + I 2164458207

$\mathrm{Fax}+\mathrm{I} 2164458024$

Email hooverj@ccf.org
Abstract: The coagulation and fibrinolytic pathways regulate hemostasis and thrombosis, and an imbalance in these pathways may result in pathologic hemophilia or thrombosis. The plasminogen system is the primary proteolytic pathway for fibrinolysis, but also has important proteolytic functions in cell migration, extracellular matrix degradation, metalloproteinase activation, and hormone processing. Several studies have demonstrated plasmin cleavage and inactivation of several coagulation factors, suggesting plasmin may be not only be the primary fibrinolytic enzyme, but may have anticoagulant properties as well. The objective of this review is to examine both in vitro and in vivo evidence for plasmin inactivation of coagulation, and to consider whether plasmin may act as a physiological regulator of coagulation. While several studies have demonstrated strong evidence for plasmin cleavage and inactivation of coagulation factors FV, FVIII, FIX, and FX in vitro, in vivo evidence is lacking for a physiologic role for plasmin as an anticoagulant. However, inactivation of coagulation factors by plasmin may be useful as a localized anticoagulant therapy or as a combined thrombolytic and anticoagulant therapy.

Keywords: thrombosis, anticoagulant, cardiovascular disease, plasminogen, protease, blood

\section{Introduction}

Thrombosis, either arterial or venous, is a fatal and disabling consequence of cardiovascular disease, the leading cause of mortality and morbidity in developed countries. ${ }^{1}$ Thrombosis occurs as a consequence of vascular injury, generally occurring at a vulnerable atherosclerotic plaque or under low-flow conditions, and imbalance between the pathways that regulate thrombus formation and/or dissolution. ${ }^{1}$ The plasminogen $(\mathrm{Plg})$ system (Figure 1) is the major proteolytic pathway responsible for dissolution of blood clots. Increased clot formation or decreased degradation is the central event in thrombotic disease. ${ }^{2,3}$ Plasmin is a broad-spectrum serine protease, and increasing evidence has implicated critical roles for Plg in the cleavage of nonfibrinolytic substrates, including extracellular matrix proteins, ${ }^{5,6}$ metalloproteinases, ${ }^{7,8}$ growth factors,,${ }^{9,10}$ hormones, ${ }^{11,12}$ and coagulation factors. ${ }^{13-17}$ Since plasmin inactivates coagulation factors by cleavage, in addition to its fibrinolytic function in the proteolytic degradation of fibrin (ogen), plasmin may also act as an anticoagulant. The purpose of this review is to examine both in vitro and in vivo evidence for plasmin inactivation of coagulation, and to consider whether plasmin may act as a physiological regulator of coagulation.

\section{Plasminogen system}

The Plg system (Figure 1) is composed of: a zymogen, Plg; the bioactive enzyme, plasmin; and the Plg activators, ie, tissue Plg activator (tPA) and urokinase Plg activator 


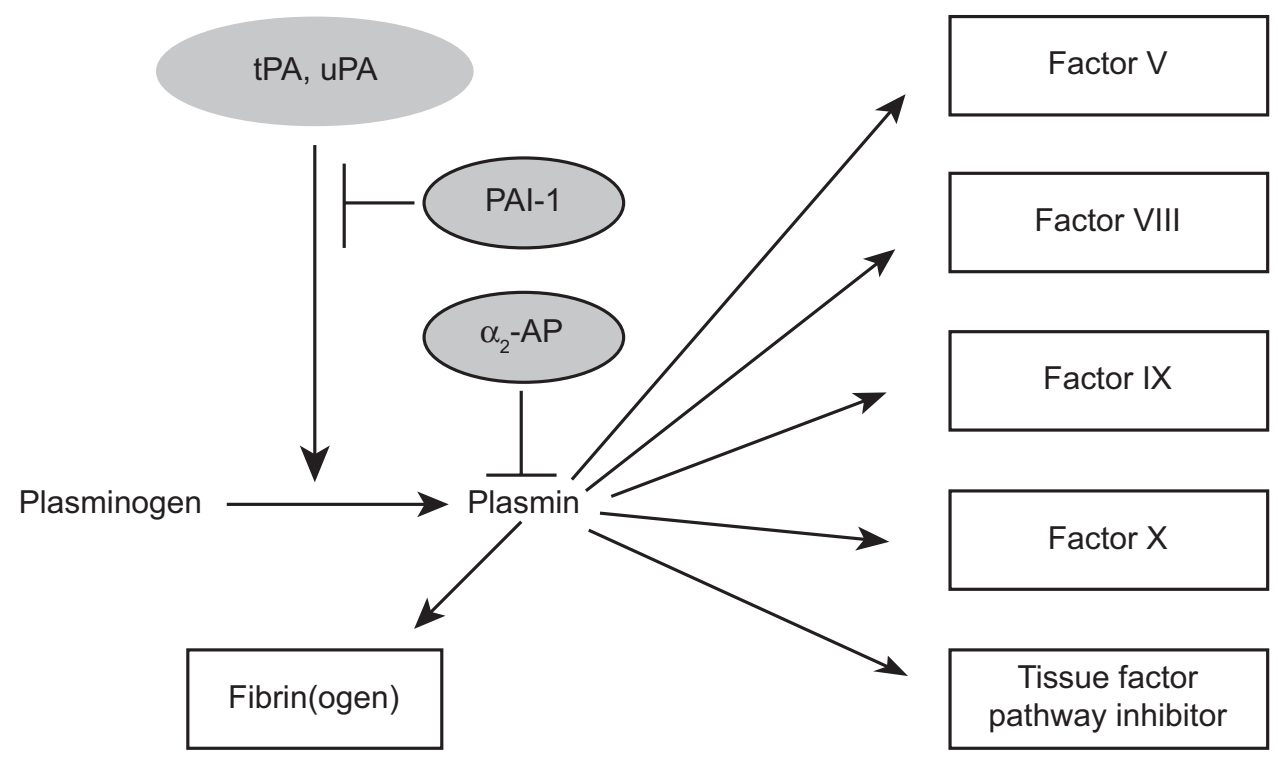

Figure I The plasminogen system.

Notes: Plasminogen activators are tPA and uPA; PAI-I inhibits tPA and uPA reducing activation of plasminogen to plasmin; $\alpha_{2}$-antiplasmin inhibits plasmin activity.

Abbreviations: PAI-I, plasminogen activator inhibitor-I; tPA, tissue plasminogen activator; uPA, urokinase plasminogen activator.

(uPA) and its primary receptor (uPAR), Plg activator inhibitors, primarily plasminogen activator inhibitor-1 (PAI-1); and the primary plasmin inhibitor, $\alpha_{2}$-antiplasmin (AP). Plg is a single-chain glycoprotein composed of five triple-loop kringle domains, and a serine protease domain. ${ }^{18}$ The kringle domains regulate the binding to inhibitors, cells, and substrates through their expression of lysine binding sites (LBS) which bind to proteins with carboxyl-terminal lysines or conformational mimetics of these residues. Plg is produced primarily by the liver, circulates in plasma at a high concentration $(2 \mu \mathrm{M})$, and is also found in high concentrations in interstitial fluid. Binding of Plg to cell surfaces and extracellular matrix accelerates its activation by Plg activators to plasmin. Plasmin is an enzyme with broad specificity, ${ }^{2}$ but the Plg activators, uPA and tPA, have much narrower specificity and are widely distributed. PAI-1 binds to uPA and $\mathrm{TPA}$, blocking their activation of Plg. AP binds initially to the LBS of plasmin and then to its catalytic site. Plasmin bound to fibrin or cell surfaces is substantially protected from AP inactivation because its LBS are occupied.

\section{Coagulation factors}

Several studies have documented the cleavage and inactivation by plasmin of coagulation factors, including Factor $(\mathrm{F}) \mathrm{V}$, FVIII, FIX, and FX (Figure 2). These coagulation factors circulate in the plasma at low concentrations, and FVIII, FIX are components of the intrinsic coagulation pathway and FV and FX are components of the prothrombinase complex in the common coagulation pathway. FV and FVIII, nonenzymatic cofactors, are similar in structure and include two A domains (copper binding) at the $\mathrm{N}$-terminus followed by a connecting $\mathrm{B}$ domain and then an $\mathrm{A} 3$ domain and $\mathrm{C}$ domain at the $\mathrm{C}$-terminal. FIX and FX are serine proteases and are similar in structure, containing heavy and light chains with a vitamin K-dependent domain, two growth factor domains and a catalytic domain.

\section{Factor $\mathrm{V}$}

$\mathrm{FV}$ is a nonenzymatic cofactor in the prothrombinase complex in the common coagulation pathway. Prothrombinase activity is required for thrombin formation and is essential for clot formation. FV is produced by the liver and megakaryocytes, circulates in the plasma, and is present in platelet a-granules. ${ }^{19}$ FVa is inactivated by plasmin cleavage in both heavy and light chains. ${ }^{13,20}$ Plasmin cleaves the heavy chain of FV at three sites, Lys309, Lys310, and Arg313, releasing the $\mathrm{A}_{2}$ domain and causing inactivation of the cofactor. ${ }^{21,22}$ The plasmin cleavages are accelerated in the presence of a membrane surface. ${ }^{21}$ Measuring thrombin formation ${ }^{20,22}$ or plasma clotting $^{21}$ determines the functional activity of FV. In humans, a deficiency of FV causes excessive bleeding. A common genetic mutation in FV, FV Leiden, inhibits protein $\mathrm{C}$, an endogenous anticoagulant, and causes persistent thrombosis. ${ }^{23}$ In mice, a FV deficiency is embryonically lethal, and FV Leiden in mice causes spontaneous thrombosis. ${ }^{24,25}$

\section{Factor VIII}

FVIII is a component of the intrinsic pathway and the primary source of circulating FVIII is the liver. FVIII is a 


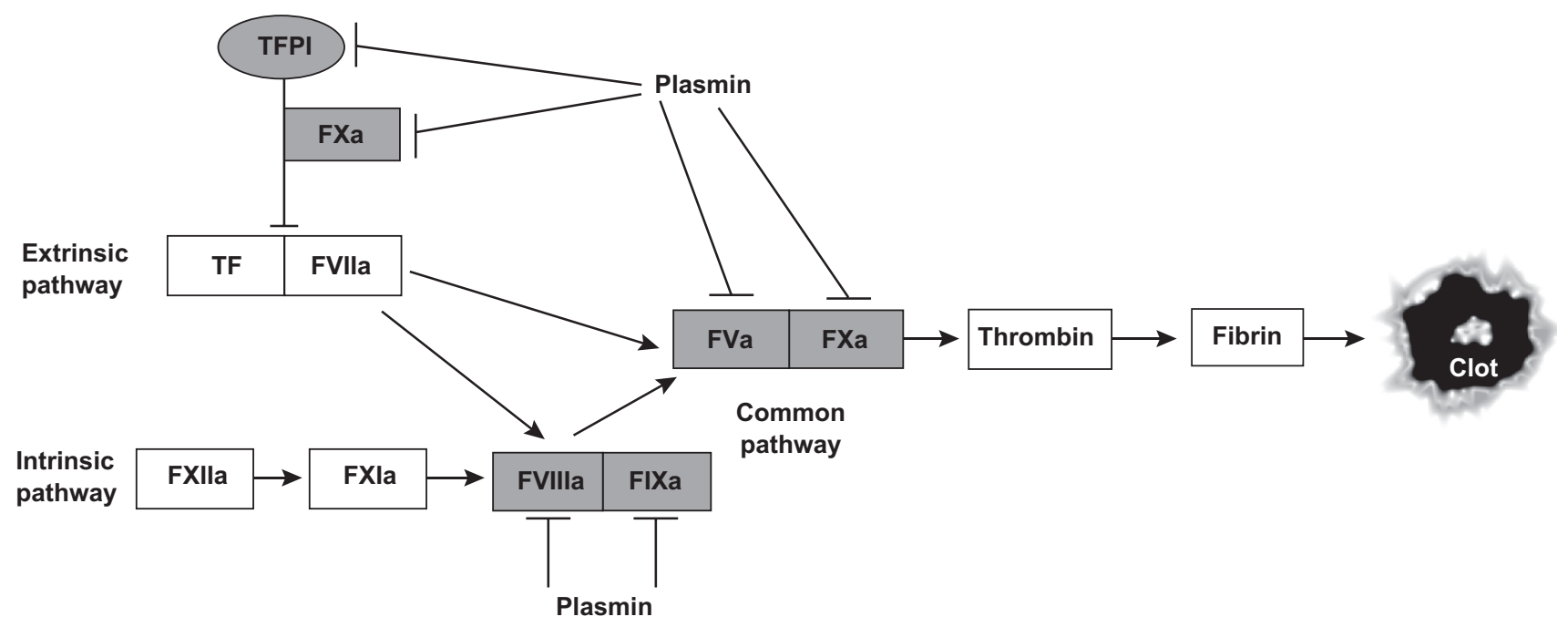

Figure 2 Plasmin substrates in the coagulation pathways.

Notes: Shaded boxes are plasmin substrates. Cleavage by plasmin inactivates the substrates. Extrinsic, intrinsic, and common pathways are indicated.

nonenzymatic cofactor, and deficient or defective protein causes a bleeding disorder, hemophilia A. FVIII is required for the anionic phospholipid surface-dependent conversion of FX to FXa by FIXa. Numerous studies have suggested that plasmin inactivates FVIII, ${ }^{14,27}$ and recently Nogami et al ${ }^{28,29}$ identified the plasmin cleavage site at Arg336 as responsible for FVIII inactivation and a plasmin interactive site in the $\mathrm{A}_{2}$ domain. Degradation of FVIII by plasmin results in a decrease in clotting activity, and deficient FVIII mice offer a model for hemophilia A. ${ }^{30}$

\section{Factor IX}

FIX is a serine protease synthesized in the liver as a singlechain glycoprotein $(57 \mathrm{kD})$, which circulates in plasma and is activated by either FXIa or tissue factor (TF) and FVIIa. Plasmin cleaves FIX at Arg145 and Arg180 and at three other sites to yield the inactivate form. ${ }^{15}$ Tissue Plg activatorcatalyzed lysis of fibrin formed in human plasma generated fragments of FIX and decreased FIX activity, ${ }^{15}$ suggesting tPA activated Plg was involved in the FIX fragmentation. Clotting time is inhibited by plasmin-cleaved FIX and FIXa fragments. Deficient mice are a model for hemophilia B and exhibit excessive tail bleeding and reduced activated partial thromboplastin time. ${ }^{31}$

\section{Factor $\mathrm{X}$}

FX is a serine protease synthesized in the liver and is a component of the prothrombinase complex that functions to generate thrombin. Plasmin-mediated cleavage of FXa exposes a Plg binding site ${ }^{16,32}$ and inhibits coagulation. In the presence of anionic phospholipid, FX and FXa enhance
Plg activation by $\mathrm{tPA}^{33,34}$ to plasmin. Thus, plasmin cleavage of FX not only inhibits coagulation but also enhances fibrinolysis. FX deficiency causes partial embryonic lethality and fatal neonatal bleeding. ${ }^{35,36}$

\section{Tissue factor protein inhibitor}

In addition to the documented cleavage by plasmin of the four coagulation factors, plasmin can inactivate the anticoagulant issue factor protein inhibitor (TFPI), a Kunitz-type protease inhibitor. TFPI with FXa inhibits the tissue factor-FVIIa complex, reducing the initiation of the extrinsic pathway. Plasmin cleaves recombinant TFPI (rTFPI) at several sites (K86-T87, R107-G108, R199-A200, K249-G250). ${ }^{15}$ rTFPI, added to plasma with uPA, is degraded, and in the presence of aprotinin, ${ }^{17}$ a catalytic inhibitor of plasmin, degradation of TFPI is abolished. Plasmin also degrades constitutive and heparin-releasable TFPI (with tPA and Plg) from human umbilical vein endothelial cells. ${ }^{37}$ Whether inactivation of TFPI would counteract the anticoagulant activity of plasmin cleavage of other factors (FV, FVIII, FIX, FX) is unclear. TFPI deficiency produces intrauterine lethality. ${ }^{38}$

\section{In vivo evidence Mouse models of thrombosis formation and lysis}

While the plasmin-cleaved coagulation factors have reduced formation of thrombin, there is little in vivo evidence for a role of plasmin inactivation of coagulation factors and TFPI. However, several studies have alluded to this possibility. Matsuno et $\mathrm{al}^{39}$ found that Plg-deficient mice had shorter arterial occlusion times after photochemical carotid injury 
(Table 1) whereas a deficiency of $\alpha_{2}$-AP, PAI-1, or vitronectin deficiency resulted in delayed occlusion times. ${ }^{39-42}$ Patency of the injured carotids was more rapid in the PAI-1 and APdeficient mice than wild-type (WT) mice (Table 1). Occlusion time of the carotid after photochemical injury was not different in mice deficient in Plg activators, uPA, or tPA, but patency was delayed in the tPA-deficient mice. ${ }^{42}$ The delay of occlusion time by plasmin/Plg inhibitors suggests a possible anticoagulant effect for plasmin. The marked delay of clot lysis time (patency) in the Plg and tPA-deficient mice and increased lysis in PAI-1 and AP is consistent with the role of plasmin in fibrinolysis. Another widely used model of thrombosis in mice is the $\mathrm{FeCl}_{3}$ injury model. In a preliminary study ${ }^{43}$ we found there was no difference between the WT $(17 \pm 2 \mathrm{sec}, \mathrm{n}=6)$ and $\mathrm{Plg}^{-/-}$mice $(18 \pm 4 \mathrm{sec}, \mathrm{n}=6)$ in occlusion time after carotid $\mathrm{FeCl}_{3}$ injury (Table 1) in contrast with the decrease found in the photochemical model. The response to $\mathrm{FeCl}_{3}$ carotid injury was similar in the PAI-1 deficient mice. ${ }^{44,45}$ With vitronectin ${ }^{-/}$mice, one report with $\mathrm{FeCl}_{3}$ injury had increased occlusion time as with photochemical injury, but one study reported a decrease. ${ }^{46}$ Clot lysis (\% carotid open after four hours) was markedly delayed in Plgdeficient mice $(17 \%, 1 / 7)$ compared with WT mice $(66 \%$, $2 / 3) .{ }^{43}$ The injury to the carotid by $\mathrm{FeCl}_{3}$ is more severe and occlusion times are faster, which may account for the lack of difference in occlusion time between WT and $\mathrm{Plg}^{-/}$mice in this model. Wang et $\mathrm{al}^{47}$ found that if a lower dose of $\mathrm{FeCl}_{3}$ was used, a delay in occlusion was detected and a difference in mice deficient in coagulation factors were detected at the lower dose, but not at the higher dose.
In a tail bleeding/rebleeding assay, ${ }^{48} \mathrm{Plg}^{-/-}$mice had increased bleeding times, but had no difference in rebleeding times (Table 2). In contrast, in PAI-1-deficient mice bleeding time was not different to that in the control strain (B6), but clot stability time was reduced, consistent with a fibrinolytic role of plasmin. The increase in bleeding time in Plg-deficient mice may be a reflection of the tissue site ${ }^{51}$ and which coagulation pathway is involved. Mackman ${ }^{49}$ found that mice with low TF and low FVII, both part of the extrinsic coagulation pathway, had normal tail bleeding, but in FVIIIor FIX-deficient mice bleeding times were increased. These results suggest that a role of plasmin as an anticoagulant may be pathway- or tissue-dependent.

\section{Regulation of TFPI}

An in vivo role for Plg in the regulation of TFPI is not clear. Stalboerger et $\mathrm{a}^{50}$ reported that TFPI is released in human artery sections by plasmin treatment, suggesting a possible increase in the anticoagulant TFPI. However, it was also suggested that plasmin may deplete TFPI in the vascular wall and contribute to rethrombosis in atherosclerotic plaque. In a sepsis-induced model in baboons, ${ }^{51}$ immunosuppression of TFPI and inhibition of PAI-1 led to a decrease in TFPI and fibrin accumulation in the lung, suggesting plasmin may play a role in proteolysis of TFPI and sepsis-induced coagulation.

\section{In vivo testing for plasmin anticoagulant activity}

Deficient mice offer potential options for testing the anticoagulant activity of plasmin in vivo. There are several

Table I Thrombosis formation and lysis after carotid injury

\begin{tabular}{|c|c|c|c|c|}
\hline Mouse genotype & Model & Time to occlusion & Patency & Reference \\
\hline $\mathrm{Plg}^{-1-}$ & Photochemical & Decreased & Decreased & 39 \\
\hline $\mathrm{AP}^{-/-}$ & & Increased & Increased & \\
\hline PAI-I-/- & Photochemical & Increased & Increased & 39,40 \\
\hline $\mathrm{AP}^{-/-}$ & & Increased & Increased & \\
\hline PAI-I-1- & Photochemical & Increased & & 41 \\
\hline $\mathrm{VN}^{-1-}$ & & Increased & & \\
\hline PAI-I-1- & Photochemical & Increased & Increased & 42 \\
\hline $\mathrm{tPA}^{-/-}$ & & $\mathrm{NC}$ & Decreased & \\
\hline $\mathrm{uPA}^{-1-}$ & & NC & $\mathrm{NC}$ & \\
\hline $\mathrm{Plg}^{-1-}$ & $\mathrm{FeCl}_{3}$ & NC & Decreased & 43 \\
\hline PAI-I ${ }^{-/-}$ & $\mathrm{FeCl}_{3}$ & ND & Increased & 44 \\
\hline PAI-I $\mathrm{I}^{-1-}$ & $\mathrm{FeCl}_{3}$ & Increased & Increased & 45 \\
\hline $\mathrm{VN}-\mathrm{I}^{-1-}$ & $\mathrm{FeCl}_{3}$ & Increased & Increased & \\
\hline $\mathrm{VN}-\mathrm{I}^{-1-}$ & $\mathrm{FeCl}_{3}$ & Decreased & ND & 46 \\
\hline
\end{tabular}

Abbreviations: AP, $\alpha_{2}$-antiplasmin; NC, no change; ND, not determined; PAI-I, plasminogen activator inhibitor-I; Plg, plasminogen; tPA, tissue plasminogen activator; uPA, urokinase plasminogen activator; $\mathrm{VN}$, vitronectin. 
Table $2 \mathrm{Plg}^{-/-}$mice have increased bleeding time and $\mathrm{PAI}-\mathrm{I}^{-1-}$ mice have reduced clot stability time in the tail bleeding/rebleeding assay

\begin{tabular}{lll}
\hline & \multicolumn{2}{l}{ Tail bleeding/rebleeding assay } \\
\cline { 2 - 3 } & Bleeding time (sec) & Rebleeding time (sec) \\
\hline $\mathrm{WT}$ & $79 \pm 5(28)^{\bullet}$ & $207 \pm 38(28)$ \\
$\mathrm{Plg}^{-{ }^{-}}$ & $130 \pm 15(9)^{*}$ & $188 \pm 86(9)$ \\
$\mathrm{B} 6$ & $99 \pm 17(34)$ & $189 \pm 25(34)^{*}$ \\
$\mathrm{PAI}-\mathrm{I}^{--}$ & $123 \pm 26(2 \mathrm{I})$ & $108 \pm 30(2 \mathrm{I})^{*}$ \\
\hline
\end{tabular}

Notes: The mouse tail is warmed in saline, clipped and remains in the saline during the time measurements. Bleeding time is the time between the start of bleeding (after tail clip) and rebleeding time is the time between the cessation of the bleeding and the start of the second bleeding. Statistical difference $\bullet P<0.05$ between WT/PIg ${ }^{+/+}$mice and $\mathrm{Plg}^{-1-}$ mice, and $* \mathrm{P}<0.0001$ for $\mathrm{B} 6$ mice compared to PAl- $\mathrm{I}^{-1-}$ mice. (Hoover-Plow et al. modified from Figure I, Ref. 48).

approaches that could be utilized to elucidate the role of plasmin in coagulation: 1) Testing the local modulation of plasmin in thrombus formation in the photochemical and $\mathrm{FeCl}_{3}$ injury models by using Plg-deficient mice and adding either microplasmin or plasmin-neutralizing antibodies or inhibitors directly to the injured carotid;2) testing small peptides that would inhibit the plasmin cleavage-specific coagulation factors; and 3) generating genetically mutated coagulation proteins in factor-deficient mice by knocking-in the mutated gene. An example would be increasing plasmin in FV Leiden mice which are prone to developing spontaneous thrombosis, to determine if thrombus formation was reduced. Thrombus formation and thrombolysis could be distinguished by following the generation of fibrin degradation products. Cheng et al ${ }^{52}$ crossed Plg-deficient and FIX mice and found reduced wasting in the double-deficient mice compared with the Plg-deficient mice; bleeding and thrombosis were not determined. Utilization of genetically altered mice offers approaches to test and define the potential of the anticoagulant activity of plasmin in vivo.

\section{Anticoagulant and thrombolytic therapy}

The two major issues to consider in the treatment of thrombotic disease are reducing thrombus formation and lysis of an existing clot. Often both factors must be treated in the same pathological situation. There are several new oral anticoagulants that are currently in clinical trials being investigated for long-term oral use. ${ }^{53,54}$ Unlike warfarin, the most widely used anticoagulant, these new anticoagulants target single proteins in the coagulation pathway and include FXa, FIX, FVII/TF, Va/VIIIa, and thrombin inhibitors. These are the same coagulation proteins that plasmin inactivates, suggesting the possibility that plasmin inactivation may be a viable anticoagulant with the added benefit of fibrinolysis.

Thrombolytic agents, primarily Plg activators or their derivates, have been developed to promote thrombolysis, but the risk of bleeding (reviewed by Ellis and Brener ${ }^{53}$ and Bottiger et al $)^{54}$ has been a major problem. Numerous clinical ${ }^{53,54}$ and animal ${ }^{55-57}$ studies have documented the potential for bleeding when tPA, the Plg activator, is administered. Bottiger et $\mathrm{a}^{54}$ reported that use of a third-generation Plg activator, tenecteplase, a tPA derivative, did not improve the outcome when used alone. Recently, strategies other than plasmin activators have been investigated, such as inhibition of the plasmin inhibitors, AP ${ }^{58}$ and PAI-1. ${ }^{59,60}$ Plasmin $^{61}$ and microplasmin, a derivative of plasmin, have also been considered for use as intravenous thrombolytics. ${ }^{62,63}$ Plasmin has several advantages as a thrombolytic drug ${ }^{61}$ including: elimination of the need for Plg and its activation; a significant margin of safety against bleeding even with high doses; a dose-response to plasma fibrinogen; and inhibition of systemic excess by AP. Prevention of thrombotic occlusion without excessive bleeding is critical in patients with myocardial infarction, ischemic stroke, abdominal aortic aneurysm, and peripheral artery disease. Topical application of plasmin is used in the treatment of macular degeneration, ${ }^{54}$ vitrectomy ${ }^{65}$ and ligneous conjunctivitis. ${ }^{66}$ Comerato $^{67}$ reports the effectiveness of catheter-directed intrathrombus thrombolysis with plasmin for the treatment of acute lower extremity arterial occlusion. Given the advantages of intravenous plasmin, a mild anticoagulant and a fibrinolytic, plasmin may be an alternative to anticoagulants and thrombolytics that have the potential to cause bleeding.

\section{Conclusions}

Plasmin cleaves and deactivates FV, FVIII, FIX, and FX in vitro and suggests another potential therapeutic strategy to regulate thrombotic occlusion. Since plasmin is one of several broad-spectrum serine proteases, cleavage by plasmin in vitro may not necessarily imply Plg plays this role in vivo. In addition, in vivo detection of an anticoagulation role of plasmin may be difficult because of its rapid thrombolytic activity. Studies in animals are suggestive of an anticoagulant effect of plasmin, but there is insufficient evidence to support a definitive role of plasmin as an anticoagulant in vivo. Mice with deficiencies in clotting factors and Plg-pathway components are suitable models for defining the in vivo role of plasmin in anticoagulation. Plasmin has recently been suggested as an ideal thrombolytic therapeutic drug, but may also confer mild anticoagulation that would be important 
when both thrombolysis and anticoagulation without excess bleeding are required. Further evidence is needed to determine whether plasmin could be used as a therapeutic agent to prevent thrombus formation.

\section{Acknowledgements}

The author thanks Subha Raghunathan and Robin Lewis for assistance with preparation of the manuscript. Supported in part by NIH HL078701.

\section{Disclosure}

The author reports no conflict of interest in this work.

\section{References}

1. Lowe GD. Common risk factors for both arterial and venous thrombosis. Br J Haematol. 2008;140:488-495.

2. Plow EF, Herren T, Redlitz A, Miles LA, Hoover-Plow JL. The cell biology of the plasminogen system. FASEB J. 1995;9:939-945.

3. Carmeliet P, Collen D. Development and disease in proteinase-deficient mice: Role of the plasminogen, matrix metalloproteinase and coagulation system. Thromb Res. 1998;91:255-285.

4. Ogura Y, Matsunaga Y, Nishiyama T, Amano S. Plasmin induces degradation and dysfunction of laminin 332 (laminin 5) and impaired assembly of basement membrane at the dermal-epidermal junction. Br J Dermatol. 2008;159:49-60.

5. Moser TL, Enghild JJ, Pizzo SV, Stack MS. The extracellular matrix proteins laminin and fibronectin contain binding domains for human plasminogen and tissue plasminogen activator. J Biol Chem. 1993;268:18917-18923.

6. Liotta LA, Goldfarb RH, Brundage GP, et al. Effect of plasminogen activator (urokinase), plasmin, and thrombin on glycoprotein and collagenous components of basement membrane. Cancer Res. 1981;41:4629-4636.

7. Lijnen HR. Plasmin and matrix metalloproteinases in vascular remodeling. Thromb Haemost. 2001;86:324-333.

8. Gong Y, Hart E, Shchurin A, Hoover-Plow J. Inflammatory macrophage migration requires MMP-9 activation by plasminogen in mice. J Clin Invest. 2008;118:3012-3024.

9. Coleman C, Tuan TL, Buckley S, Anderson KD, Warburton D. Contractility, transforming growth factor-beta, and plasmin in fetal skin fibroblasts: Role in scarless wound healing. Pediatr Res. 1998;43: 403-409.

10. Shanmukhappa K, Matte U, Degen JL, Bezerra JA. Plasmin-mediated proteolysis is required for hepatocyte growth factor activation during liver repair. J Biol Chem. 2009;284:12917-12923.

11. Wang N, Zhang L, Miles L, Hoover-Plow J. Plasminogen regulates pro-opiomelanocortin processing. J Thromb Haemost. 2004;2: 785-796.

12. Jiang QJ, Taupenot L, Mahata SK, et al. Proteolytic cleavage of chromogranin A $(\mathrm{CgA})$ by plasmin - selective liberation of a specific bioactive $\mathrm{CgA}$ fragment that regulates catecholamine release. $J$ Biol Chem. 2001;276:25022-25029.

13. Omar MN, Mann KG. Inactivation of factor Va by plasmin. J Biol Chem. 1987;262:9750-9755.

14. Pasquini R, Hershgold EJ. Effects of plasmin on human factor VIII (AHF). Blood. 1973;41:105-111.

15. Samis JA, Ramsey GD, Walker JB, Nesheim ME, Giles AR. Proteolytic processing of human coagulation factor IX by plasmin. Blood. 2000;95:943-951.

16. Pryzdial EL, Kessler GE. Autoproteolysis or plasmin-mediated cleavage of factor Xaalpha exposes a plasminogen binding site and inhibits coagulation. J Biol Chem. 1996;271:16614-16620.
17. Li A, Wun TC. Proteolysis of tissue factor pathway inhibitor (TFPI) by plasmin: Effect on TFPI activity. Thromb Haemost. 1998;80: 423-427.

18. Collen D. The plasminogen (fibrinolytic) system. Thromb Haemost. 1999;82:259-270.

19. Hayward CP, Furmaniak-Kazmierczak E, Cieutat AM, et al. Factor V is complexed with multimerin in resting platelet lysates and colocalizes with multimerin in platelet alpha-granules. J Biol Chem. 1995;270:19217-19224.

20. Lee CD, Mann KG. Activation/inactivation of human factor V by plasmin. Blood. 1989;73:185-190.

21. Kalafatis M, Mann KG. The role of the membrane in the inactivation of factor Va by plasmin. Amino acid region 307-348 of factor $\mathrm{V}$ plays a critical role in factor Va cofactor function. J Biol Chem. 2001;276:18614-18623.

22. Zeibdawi AR, Pryzdial EL. Mechanism of factor Va inactivation by plasmin. Loss of A2 and A3 domains from a Ca2+-dependent complex of fragments bound to phospholipid. J Biol Chem. 2001;276: 19929-19936.

23. Rosendorff A, Dorfman DM. Activated protein $\mathrm{C}$ resistance and factor $\mathrm{V}$ Leiden: A review. Arch Pathol Lab Med. 2007;131:866-871.

24. Cui J, O'Shea KS, Purkayastha A, Saunders TL, Ginsburg D. Fatal haemorrhage and incomplete block to embryogenesis in mice lacking coagulation factor V. Nature. 1996;384:66-68.

25. Cui J, Eitzman DT, Westrick RJ, et al. Spontaneous thrombosis in mice carrying the factor V Leiden mutation. Blood. 2000;96:4222-4226.

26. Donati MB, de GG, Vermylen J, Verstraete M. Inhibition of human platelet aggregation by plasmin digests of human factor VIII. Blood. 1973;42:749-751.

27. Rick ME, Krizek DM. Platelets modulate the proteolysis of factor VIII: C protein by plasmin. Blood. 1986;67:1649-1654.

28. Nogami K, Freas J, Manithody C, et al. Mechanisms of interactions of factor $\mathrm{X}$ and factor $\mathrm{Xa}$ with the acidic region in the factor VIII A1 domain. J Biol Chem. 2004;279:33104-33113.

29. Nogami K, Nishiya K, Saenko EL, et al. Identification of a plasmininteractive site within the A2 domain of the factor VIII heavy chain. Biochim Biophys Acta. 2008;1784:753-763.

30. Bi L, Lawler AM, Antonarakis SE, et al. Targeted disruption of the mouse factor VIII gene produces a model of haemophilia A. Nat Genet. 1995;10:119-121.

31. Monahan PE. Factor IX: Insights from knock-out and genetically engineered mice. Thromb Haemost. 2008;100:563-575.

32. Pryzdial ELG, Lavigne N, Dupuis N, Kessler GE. Plasmin converts factor $\mathrm{X}$ from coagulation zymogen to fibrinolysis cofactor. $\mathrm{J}$ Biol Chem. 1999;274:8500-8505.

33. Grundy JE, Lavigne N, Hirama T, MacKenzie CR, Pryzdial ELG. Binding of plasminogen and tissue plasminogen activator to plasminmodulated factor X and factor Xa. Biochemistry. 2001;40:6293-6302.

34. Grundy JE, Hancock MA, Meixner SC, et al. Plasminogen binds to plasmin-modulated factor $\mathrm{Xa}$ by $\mathrm{Ca}(2+)$ - and C-terminal lysinedependent and -independent interactions. Thromb Haemost. 2007;97: $38-44$.

35. Dewerchin M, Liang Z, Moons L, et al. Blood coagulation factor X deficiency causes partial embryonic lethality and fatal neonatal bleeding in mice. Thromb Haemost. 2000;83:185-190.

36. Tai SJ, Herzog RW, Margaritis P, et al. A viable mouse model of factor $\mathrm{X}$ deficiency provides evidence for maternal transfer of factor $\mathrm{X}$. J Thromb Haemost. 2008;6:339-345.

37. Li Y, Spencer FA, Becker RC. Plasmin-mediated proteolysis of vascular endothelial cell heparin releasable tissue factor pathway inhibitor. J Thromb Thrombolysis. 2003;15:19-23.

38. Huang ZF, Higuchi D, Lasky N, Broze GJ Jr. Tissue factor pathway inhibitor gene disruption produces intrauterine lethality in mice. Blood. 1997;90:944-951.

39. Matsuno H, Kozawa O, Okada K, et al. Plasmin generation plays different roles in the formation and removal of arterial and venous thrombus in mice. Thromb Haemost. 2002;87:98-104. 
40. Kawasaki T, Dewerchin M, Lijnen HR, Vermylen J, Hoylaerts MF. Vascular release of plasminogen activator inhibitor-1 impairs fibrinolysis during acute arterial thrombosis in mice. Blood. 2000;96:153-160.

41. Eitzman DT, Westrick RJ, Nabel EG, Ginsburg D. Plasminogen activator inhibitor-1 and vitronectin promote vascular thrombosis in mice. Blood. 2000;95:577-580.

42. Matsuno H, Kozawa O, Niwa M, et al. Differential role of components of the fibrinolytic system in the formation and removal of thrombus induced by endothelial injury. Thromb Haemost. 1999;81:601-604.

43. Hoover-Plow J, Hart E, Saraniti J. Apo(a) increases clot stability in transgenic mice. J Thromb Haemost. 2009;7(Suppl 2):Abstract PP-WE-239.

44. Farrehi PM, Ozaki CK, Carmeliet P, Fay WP. Regulation of arterial thrombolysis by plasminogen activator inhibitor-1 in mice. Circulation 1998;97:1002-1008.

45. Konstantinides S, Schäfer K, Thinnes T, Loskutoff DJ. Plasminogen activator inhibitor- 1 and its cofactor vitronectin stabilize arterial thrombi after vascular injury in mice. Circulation. 2001;103:576-583.

46. Zhu Y, Carmeliet P, Fay WP. Plasminogen activator inhibitor-1 is a major determinant of arterial thrombolysis resistance. Circulation. 1999;99:3050-3055.

47. Wang X, Cheng Q, Xu L, et al. Effects of factor IX or factor XI deficiency on ferric chloride-induced carotid artery occlusion in mice. J Thromb Haemost. 2005;3:695-702.

48. Hoover-Plow J, Shchurin A, Hart E, et al. Genetic background determines response to hemostasis and thrombosis. BMC Blood Disord. 2006;6:6.

49. Mackman N. Tissue-specific hemostasis in mice. Arterioscler Thromb Vasc Biol. 2005;25:2273-2281.

50. Stalboerger PG, Panetta CJ, Simari RD, Caplice NM. Plasmin proteolysis of endothelial cell and vessel wall associated tissue factor pathway inhibitor. Thromb Haemost. 2001;86:923-928.

51. Tang H, Ivanciu L, Popescu N, et al. Sepsis-induced coagulation in the baboon lung is associated with decreased tissue factor pathway inhibitor. Am J Pathol. 2007;171:1066-1077.

52. Cheng Q, Zhao Y, Lawson WE, et al. The effects of intrinsic pathway protease deficiencies on plasminogen-deficient mice. Blood. 2005;106:3055-3057.

53. Ellis K, Brener S. New fibrinolytic agents for MI: As effective as current agents, but easier to administer. Cleve Clin J Med. 2004;71:20-27.
54. Bottiger BW, Arntz HR, Chamberlain DA, et al. Thrombolysis during resuscitation for out-of-hospital cardiac arrest. $N$ Engl J Med. 2008;359:2651-2662.

55. Gautier S, Petrault O, Gele P, et al. Involvement of thrombolysis in recombinant tissue plasminogen activator-induced cerebral hemorrhages and effect on infarct volume and postischemic endothelial function. Stroke. 2003;34:2975-2979.

56. Thomas GR, Thibodeaux H, Errett CJ, et al. A long-half-life and fibrinspecific form of tissue plasminogen activator in rabbit models of embolic stroke and peripheral bleeding. Stroke. 1994;25:2072-2078.

57. Suzuki Y, Nagai N, Collen D. Comparative effects of microplasmin and tissue-type plasminogen activator (tPA) on cerebral hemorrhage in a middle cerebral artery occlusion model in mice. J Thromb Haemost. 2004;2:1617-1621.

58. Sazonova IY, Thomas BM, Gladysheva IP, Houng AK, Reed GL. Fibrinolysis is amplified by converting alpha-antiplasmin from a plasmin inhibitor to a substrate. J Thromb Haemost. 2007;5:2087-2094.

59. Wu Q, Zhao Z. Inhibition of PAI-1: A new anti-thrombotic approach Curr Drug Targets Cardiovasc Haematol Disord. 2002;2:27-42.

60. Westrick RJ, Eitzman DT. Plasminogen activator inhibitor-1 in vascular thrombosis. Curr Drug Targets. 2007;8:966-1002.

61. Marder VJ. Thrombolytic therapy for deep vein thrombosis: Potential application of plasmin. Thromb Res. 2009;123:S56-S61.

62. Nagai N, Demarsin E, Van Hoef B, Wouters S, Cingolani D. Recombinant human microplasmin: Production and potential therapeutic properties. J Thromb Haemost. 2003;1:307-313.

63. Lapchak PA, Araujo DM, Pakola S, et al. Microplasmin: A novel thrombolytic that improves behavioral outcome after embolic strokes in rabbits. Stroke. 2002;33:2279-2284.

64. Diaz-Llopis M, Udaondo P, Arevalo F, et al. Intravitreal plasmin without associated vitrectomy as a treatment for refractory diabetic macular edema. J Ocul Pharmacol Ther. 2009;25:379-384.

65. Gandorfer A. Microplasmin-assisted vitrectomy. Dev Ophthalmol. 2009;44:26-30.

66. Watts P, Suresh P, Mezer E, et al. Effective treatment of ligneous conjunctivitis with topical plasminogen. Am J Ophthalmol. 2002;133: $451-455$.

67. Comerota AJ. Development of catheter-directed intrathrombus thrombolysis with plasmin for the treatment of acute lower extremity arterial occlusion. Thromb Res. 2008;122:S20-S26.
Vascular Health and Risk Management

\section{Publish your work in this journal}

Vascular Health and Risk Management is an international, peerreviewed journal of therapeutics and risk management, focusing on concise rapid reporting of clinical studies on the processes involved in the maintenance of vascular health; the monitoring, prevention and treatment of vascular disease and its sequelae; and the involvement of

\section{Dovepress}

metabolic disorders, particularly diabetes. This journal is indexed on PubMed Central and MedLine. The manuscript management system is completely online and includes a very quick and fair peer-review system, which is all easy to use. Visit http://www.dovepress.com/ testimonials.php to read real quotes from published authors. 